\title{
History of health, a valuable tool in public health
}

\author{
E Perdiguero, J Bernabeu, R Huertas, E Rodríguez-Ocaña
}

\begin{abstract}
The aim of this article is to highlight the importance of the history of public health for public health research and practice itself. After summarily reviewing the current great vitality of the history of collective health oriented initiatives, we explain three particular features of the historical vantage point in public health, namely the importance of the context, the relevance of a diachronic attitude and the critical perspective. In order to illustrate those three topics, we bring up examples taken from three centuries of fight against malaria, the so called "re-emerging diseases" and the 1918 influenza epidemic. The historical approach enriches our critical perception of the social effects of initiatives undertaken in the name of public health, shows the shortcomings of public health interventions based on single factors and asks for a wider time scope in the assessment of current problems. The use of a historical perspective to examine the plurality of determinants in any particular health condition will help to solve the longlasting debate on the primacy of individual versus population factors, which has been particularly intense in recent times.
\end{abstract}

(F Epidemiol Community Health 2001;55:667-673)

In recent years, the growing interest of historians in public health has added complexity and refinement to the historical analysis of the problems involved in collective actions directed against disease and towards improvements in health. Visible steps of this process are the series of conferences convened by the International Network for the History of Public Health (Lövik, 1991; Liverpool, 1997; Almuñecar, 1999; Norrköping, 2001), the Network's recently launched electronic journal Hygiea Internationalis, ${ }^{1}$ the steady progress of the journal Social History of Medicine (Oxford, 1988 to date) and the recent changes in editorial policy at the older fournal of the History of Medicine and Allied Sciences (New Haven, 1946 to date), as well as a large number of new general books, monographs and readers. ${ }^{2-11}$ Concepts and hypotheses arising from developments in the broad field of social sciences have been instrumental in promoting a refinement of history's own methods and approaches in regard to public health. ${ }^{12} 13$

The contribution of the history of public health to the actual practice of public health also deserves recognition. In Labisch's words, using an old distinction first applied to the relation of social sciences and medicine, ${ }^{14}$ rather than the history of public health, there is a need to deal with history in public health, as shown in recent pieces by Elizabeth $\mathrm{Fee}^{15}$ and Virginia Berridge. ${ }^{16}$ The aim of this article is to summarise these general contributions within a framework of examples, mainly drawn from our own experience as historians of medicine. A great deal of our research work has been devoted to the study of issues related to the history of public health. ${ }^{17-27}$ We wish to contribute to the ongoing critical assessment of research methods in epidemiology, emphasising the weight of history within the set of conditions studied to explain disease in human populations. $^{28-31}$

Two of the present authors are members of university public health departments and lecture on both history and public health in various university courses in the health domain (including medicine, nursing, pharmacy, physiotherapy, chiropody, psychology). Over the past 15 years, this situation has enabled us to share concerns and discuss with our public health colleagues on a daily basis. These contacts have shown us what historians can learn from public health professionals and what public health professionals can learn from historians. It is the second aspect that now deserves further consideration. Moreover, we all shared a meeting place at the regular "Marcelino Pascua" workshops. Marcelino Pascua (1897-1977) was a Spanish health statistician, socialist and Rockefeller Foundation fellow, who held an important position at the newly founded WHO, and workshops held in his name have brought together public health practitioners and historians in recent years. $^{32}$

We should point out some evident methodological differences. Public health methods, particularly those pertaining to the field of epidemiology, place emphasis on the quantitative aspect, whereas we historians usually prefer a number of methodologies that could be considered as qualitative. Debates are typically polarised between concerns about representation or reproduction possibilities and issues related to meaning and relevance. ${ }^{15}$ However, beyond the technical tools to be used, the key issues should be the ways to identify a problem, the questions to be considered and the possibilities to adopt critical positions.

We wish to explain three particular features of the historical vantage point in public health, namely the importance of the context, the relevance of a diachronic attitude and the critical perspective. We shall first offer an outline history of the relation between the two disciplines. 


\section{History and public health}

It is worth remembering that during the 18th and early 19th century there was a mutual hybridisation between history and epidemiology (that is, the science of epidemics, or diseases affecting large numbers of a given population), with the first pragmatically used as a source of practical knowledge and the second contributing to the creation of the history of medicine as a specialised discipline. ${ }^{33}{ }^{34}$ The subject "History of medicine and epidemiology" 35 "was introduced in medical schools such as those in Vienna or Berlin. The earliest international initiatives associated with the history of medicine were related to "historicogeographic pathology", in parallel with the gestation of international agreements on health related matters. During the second period of its existence, the journal Fanus (Gotha, 185153) - one of the first attempts to publish a periodical in this field-was subtitled the Central-Magazin für Geschichte und Literargeschichte der Medicin, ärtzliche Biographik, Epidemiographik, medicinische Geographik und Statistik, and, during its third period (Amsterdam, 1896-1941) it was subtitled Archives d'histoire de la médecine et géographie médicale.

Since the laboratory was incorporated into public health practice in the last decades of the 19th century and a specific nucleus of knowledge and techniques was established as the basis for training and recruiting programmes, history has been used by public health practitioners in two main ways. Firstly, as a contributory history, a permanent record of successes that generates genealogical legitimisation while helping to create an esprit de corps through the dissemination of a set of self affirmative principles and values. ${ }^{37}$ Secondly, as a support to authors in defending particular theoretical positions on the explanation of health and disease, the organisation of care, and the role of prevention.

The first of these two purposes emerged with the addition of a historical chapter, sometimes very sophisticated, to treatises on the discipline. ${ }^{17}{ }^{38-42}$ The second purpose can be seen in the use of history as a weapon in times of trouble, such as in the discussions on the aim and methods of public health at the birth of social hygiene/medicine and as a classic feature of the development of the latter after the second world war. Authors such as George Rosen (1910-1977), who lectured on public health and history of medicine at Columbia and Yale Universities (USA), and Thomas McKeown (1912-1988), Professor of Social Medicine at Birmingham University (UK), are well known examples. For both authors, the use of history constituted the core framework on which hypotheses and theories directly oriented towards the present are founded and clarified. Rosen, following his mentor Henry E Sigerist (1891-1957), resorted to history in order to show that health and disease are biological and social processes and that medicine and public health professionals, as agents in the progress of mankind, play political and social parts that go beyond care. ${ }^{43} \mathrm{He}$ asserted that awareness of history could help public health practitioners to lead the way in transforming society. McKeown, who held a much more sceptical view of the real effects of medicine and health care services on the health of the population, strongly supported the replacement of a commemorative history with a political history. His position was that a true social history should start with issues that arise from current problems, in order to clarify them and contribute to the design of health policies and decision making processes. ${ }^{44}$ This approach can be observed in present day debates, where history is chosen as a point of departure for new research paths. ${ }^{4-49}$

The starting point of our discussion is the perspective that public health history is part of the scientific armoury of public health itself.

\section{The relevance of the context}

The use of history in public health highlights the importance of contextualising health problems and contributes decisively to the genesis of a theory of the social conditioning of health and disease processes. In other words, it helps to make public health experts aware of the complexity of the social, cultural, political and economical circumstances that frame each particular case.

Modern epidemiology, with the implementation of the risk model through an increasingly complex methodology, singles out risk factors to explain the loss of health and the onset of disease, while ignoring the broader setting of the interactions and meanings of these factors. ${ }^{48}$ Accordingly, a preventive discourse has developed that focuses on the behaviour of individuals, ruling out any further consideration of the universe of intermingled economic, social, cultural and political conditions of human life in society.

It is our contention that historical experience, as shown by historical studies, exposes the shortcomings of a de-contextualised intervention based on single factors.

The serious health problem of malaria illustrates our point. Spain is one of the southern European countries where this disease took a heavy toll during the past three centuries. In the 18th century, the attempts to fight malarial fevers in large territories of the Iberian Peninsula $a^{50-56}$ were based on environmental approaches consistent with miasmatic ideas. This entailed, for example, limiting the areas dedicated to rice growing. From an aetiological point of view, it was clear that the nearer the populations settled to the waterlogged fields, the higher was the incidence of the debilitating fevers. Thus, health action should be geared to the limitation of rice growing areas. More than one century later, the parasitological theory was established and the insect carrier was detected, leading to measures designed to interrupt the contagion mechanism. The elimination of the parasite reservoir was sought through the administration of quinine to ill subjects, the destruction of the anopheles larvae, individual and collective protection against bites, and, when chemical insecticides became available, the elimination of the vector. 
Drugs and mosquitos became the main targets for research into preventive measures.

Both in the 18th and 20th centuries, public health and political authorities tried to intervene against certain environmental or biological factors in accordance with the accepted scientific theory of the time. However, these strategies came into conflict with the economic and the cultural interests of populations. In the 18 th century, official limits on the extension of rice growing in areas where it represented a major source of wealth caused growing unrest and the illegal spreading of rice growing territories. The persistence of malaria for centuries made it such a familiar condition to rural populations that it was integrated within the parameters of normal life, so that the disease was often ignored, with no medical advice sought. Confidence in quinine and mosquito oriented measures in the early 20th century led to further outbreaks of malaria, even in new territories, caused in part by the implementation of extensive hydraulic works (in many cases, in order to extend rice cultures). Another factor in the spread of the disease was the migration of populations. In times of peace, through the opportunities created by the newly irrigated lands, and, in times of war, as a direct consequence of military actions, as illustrated by the well known consequences of the presence of Allied troops in the Balkans during the first world war. The attack on the contagion chain was a necessary measure but inadequate to wipe out malaria, because the problem was connected to a plurality of contextual conditions. For example, fundamental parts were played by the poverty of the peasant population, a product of the structure of land and property, and by the work systems and living conditions. Malaria was only defeated where there were parallel improvements in all of these conditions, as in Spain and other European countries between the 1920s and 1960s. Where this did not occur, as in Latin America, South East Asia or sub-Saharan Africa, malaria still stands as one of the most serious health issues. ${ }^{57}$ Some malariologists of the interwar era sought to separate biological and social problems in the explanation of malaria, convinced that the health campaigns directed against it should only include biological measures. This was the view held by Rockefeller Foundation officers, as expressed by Lewis Hackett in his Malaria in Europe, published in $1937 .^{58}$ However, awareness of defeat was sufficiently great by the early 1950 s for defenders of the isolationist position to recognise the inextricable link between health and context: "The problem is much broader than health, which cannot flourish in an adverse socioeconomic environment" (W A Sawyer, 1951). ${ }^{59}$ Nevertheless, today's campaigns against malaria in sub-Saharan Africa reveal the same level of conflict and debate on the importance of one or another single factor in the epidemiology of malaria as existed in interwar Europe, with many of the same exclusive, decontextualised doctrines of prevention still being defended. ${ }^{60}$
After the so called epidemiological revolution or transition, ${ }^{61}$ the aetiopathogenic features of chronic, mostly non-infectious diseases made the above mentioned singling out of "risk factors" even easier. The triumph of this paradigm can be seen in the mass media stereotypes and messages that daily reach the public. The aim is to change individual behaviour, with much less emphasis placed on circumstances that have a major influence on the health of populations, such as wealth distribution, loss of work, quality of dwellings, or hygienic conditions at shop level. The taint of "politics" seems to bar their mention from scientific, professional literature, because they are factors linked to the economic and sociopolitical sphere of society, independent from the will of individuals. This represents a major obstacle to any substantial developments in the detection of pathological forms of relation between the social and the biological realms that could lead to feasible public health actions. Hamlin situates within this contradiction the path followed by the British sanitary movement in the times of Chadwick. ${ }^{10}$

The emphasis on individual behaviours ignores the fact that these behaviours are, inasmuch as they refer to cultural practices, the polymorphous expression of ways of life and models of production and consumption. The problem cannot be reduced to the simple "will" and responsibility of the subject to modify an "unhealthy" behaviour and adopt "healthy" life habits. It is necessary to distinguish between "lifestyle", formed by a set of individual behaviour habits, and the "way of life" of differentiated social groups. "Lifestyle" commonly refers to six concrete problems (tobacco, physical exercise, social integration, alcohol, drugs and nutrition), whereas "way of life" is systematically defined by the economic, sociopolitical and cultural conditions of the characteristic, repeated and stable, daily lives of individuals and collectives. The differences in ways of life are well known and expressed in terms of hygienic habits, nutritional intake, housing quality, working conditions, etc, and in terms of how individuals take on the values, ideals and objectives of social classes. ${ }^{62} 63$

This analysis is evidently related to the Gramscian concept of social hegemony, whose concretion at each historic moment reveals the relation between disease and social inequality, among others, going beyond the above mentioned tendency to individualise health problems. This is the framework in which to view the adoption by the population of "risk behaviours": as identity models, as ways to achieve relationship patterns and resolve conflicts within the social stratum to which the population belongs. ${ }^{64-66}$ This broad understanding can be fostered by the practice of history.

If we consider the field of environmental risks, we must ask ourselves why it was so difficult to translate the knowledge we acquired on the toxicity of substances such as lead or asbestos into efficacious preventive measures. This illustrates the contradiction between the existence of a complex framework of interrelated causes and effects in all dimensions of social 
life and the pressure from industry to specify simple causal models, especially through experimental laboratory research. ${ }^{67}$

In the light of these reflections, it seems opportune to introduce broader perspectives into epidemiological research use, as has been proposed in recent years, despite the methodological difficulties. ${ }^{68} 69$

\section{The time perspective}

The second vantage point that we would like to mention here is that of the "time perspective" and the social changes that take place within human groups. Broadly speaking, and without too strict a use of historical terminology, we could say that public health is much more concerned with the short-term than with the Braudelian longue durée. This is understandable. Health problems are urgent, they affect human lives, and immediate actions are required to cope with them. However, problems are very often the result of tendencies that have been evolving over the centuries or at least derive from changes that have been occurring for decades. Our own rational tools for understanding come from distinct traditions that have been operating for several or many decades. Our world still revolves around ideas (for example, progress, common good, capitalism, liberalism, communism, human rights) that derive from the 17 th, 18 th and 19th centuries. Current doctrines on the causes of health and disease have been formed throughout centuries, evolving from medieval Aristotelian ideas, ${ }^{70}$ not to mention the impact of the evolving material basis of our technological culture. The increasing participation of women in the labour market and the greater longevity of humans beings have, along with the reduction in the levels of infant mortality, radically modified the structure of populations. But these far reaching changes have been operating for many years to produce effects that can only now be observed. Knowledge of history, of the history of sciences and of the history of medicine and public health itself is a technical imperative if we are to develop the widest capacities of the public health profession.

Moreover, many health problems would be much better tackled if we could situate themand the affected populations - in a wider time span in order to explain their current situation. ${ }^{71}$ History is a highly useful tool for public health because our understanding of a given problem can improve if we study its historical evolution. Any situation can be much better explained if attention is paid to the circumstances that have led to it and if adequate consideration is taken of the broad social changes that have occurred. ${ }^{14}$ One of the most suggestive examples rests with the importance that the so called "re-emerging diseases" have acquired during the past decades. ${ }^{72}$ The interpretation of these problems is usually confined to the most immediate, mostly biological factors. However, a consistent contribution of contemporary historiography has been to show the weight of sociocultural considerations in drawing up proposals for health intervention. ${ }^{73-77}$ And when situated in their own context, the health problems associated with many of these diseases are closely linked with some of the above mentioned structural factors. The present situation is the result of a given historical array of changing - even nonexistent - health policies in a complex frame of groups and interests, both national and international. The generalised application of the recently popular concept of "globalisation" is no substitute for the study of the historical evolution of markets in order to develop our understanding of the processes involved. ${ }^{78} 79$

\section{The critical view}

The last point we would like to mention is concerned with reflection upon the consequences of public health actions. At first sight, any initiative to keep disease and death away would seem to be beneficial for the whole society. Things are not so straightforward, however, and numerous studies over recent decades have shown that actions carried out in the name of public health can be interpreted in many different ways. ${ }^{138081}$ These actions have an effect on different domains of social reality and not necessarily always in the same direction. Thus, the social significance of public health related actions and decisions must be considered. At this stage, history is again a useful tool to develop a critical perspective on public health. Our direct contact with public health workers and researchers has shown us that it is not always easy to gain this kind of awareness about the social scope of their activities. However, the attempt to locate the purpose of the action and the part it plays in the social matrix sheds considerable light on public health work itself. The lines of thought that have opened up in recent decades are very varied and illustrate different positions that are worthy of consideration. After the optimistic confidence in the victory of science, most notably expressed by George Rosen ${ }^{82}{ }^{83}$ new ways to understand the general path followed by public health have multiplied. ${ }^{108485}$ Some researchers follow orthodox analyses stemming from political economy, which assume that any strategies to improve health are just a way to reproduce the workforce placed at the service of the ruling class. Others emphasise the relation of public health interventions to power and social control issues, to surveillance and discipline. There are also those who regard health as a melting pot that can be used to explain many of the features and identities of our time. Without necessarily rejecting these approaches, some researchers have taken a particular interest in a unified approach to public health within the framework of wider health policies, analysing the greater or lesser degree of interrelation (coordination) between preventive and health care initiatives over time. They have taken account of the context of the health systems, which have themselves been modified, both in their theoretical foundations and practical aims for the health condition of populations, as a result of the ups and downs of economic policy. ${ }^{638687}$

It is therefore possible to use the historical approach to enrich our perception of the social 
effects of research and intervention initiatives undertaken in the name of public health. For example, when the so called exotic epidemic threats appeared one after the other throughout the 19th century, clear discrepancies were found among the different countries in their application of general protection measures, particularly as regards international transport and trade. Baldwin ${ }^{11}$ has rigorously examined the national origins of these discrepancies, which only disappeared when the toughest measures, those which most distorted the daily life of the peoples affected, were shifted towards the eastern limits of the European area of influence. ${ }^{77}$

During the influenza epidemic in $1918,{ }^{88-90}$ a public health oriented action was taken in Alicante, a Spanish city located in the Mediterranean coast, which ended with the demolition of an entire area of the city and the expulsion of its inhabitants. The local authorities, following the advice of public health officers and in the context of what the mass media of the time defined as a "health dictatorship", argued their case as follows. The fact that the most disadvantaged socioeconomic sectors were the most seriously affected by the epidemic established an association between the disease and the conditions of poverty and unhealthiness in which a large number of these families lived. The houses they occupied came to be considered as real sources of infection and even the origin of the disease itself, with the occupants becoming the vehicles for spreading disease and contagion. Based on this analysis, an intervention process was developed that ended up with the evacuation and demolition of an entire district of the city. This led to the segregation of some of its inhabitants, most of whom were concentrated in an old castle and the expulsion of another major population group, for whom, euphemistically, "the return to their places of origin was made easier". In other words, the non-native population was removed from the city to avoid the spreading of disease. ${ }^{91} 92$ There are hundreds of similar examples. The connection between the interests of the ruling class, morals and hygiene has been very common throughout history and has been applied to all sorts of problems. ${ }^{93}$ Nowadays, we still find ourselves faced by similar situations and it is in precisely this context that the historical approach is of value to offer a critical view of certain initiatives undertaken in the name of public health. One example is provided by Didier Fassin's study of the link between health assumptions and urban policies in present day Paris, which underlined the risk that public health arguments might be used to legitimise social exclusion policies. ${ }^{94}$

With regard to the risk model, the behaviourist approach has been subject to criticism both when applied in the name of the "new public health" approach and when incorporated into the most traditional preventive strategies. Many of these strategies insist on the need to discipline and blame the population ${ }^{95}$ in order to achieve the indisputable and self explained good of health. However, it is of paramount importance to situate health in its historical dimension so as to clarify its actual meaning at each historical stage. ${ }^{297}$ According to David Armstrong, ${ }^{98}$ who elaborated on dichotomies already used by Durkheim ${ }^{99}$ on the profane and the sacred, and Douglas, ${ }^{100}$ who explored the concepts of the clean and the dirty, many of the public health strategies adopted in the past two centuries can indeed be regarded as core programmes within political or socioeconomic projects. At the same time, these strategies have been instrumental to set apart different social groups and have implied the successive introduction of governmentality into an increasing number of life situations through the institutionalisation of expertise. ${ }^{101} 102$ Finally, shifting hygienic rules and public health practices have delineated changing spaces for personal identities throughout history. ${ }^{98}$ Most of these works followed the Foucaultian tradition ${ }^{103} 104$ and were superseded by other critical positions coming from postmodernism ${ }^{105}$ and gender studies. ${ }^{106}$

\section{Conclusion}

We believe that the history of public health should be accorded its rightful place among public health concepts and methods. In other words, we posit a process of hybridisation between both disciplines in order to overcome the limitations in scope and understanding that we have underscored in this paper. The hallmarks of the historical approach, the consideration of problems in their context, the time scope and the critical perspective should become common tags in public health's inner schemes of work. After all, public health as scientific activity is but a mixture of diverse knowledge and practices brought together by a focus on a given population. Furthermore, the content of public health is unavoidably bound to locality in so far as it refers to the living conditions and practical life of human groups, an aspect that a historical view would strengthen.

Some new epidemiological research is already widening the time span for observations and seeks to gather data related to earlier periods of life of the populations under scrutiny. ${ }^{107}$ There are also various cohort studies that are designed to gather personal data over decades. Data interpretation should overcome the shortcomings of the risk model. It should not be limited to the consideration of singular events in the past but should rather rely on contextual information. For instance, historical research on the incidence of water supply in infant and childhood mortality showed the difficulties of usng a single factor to explain shifts in the health conditions of a given population. ${ }^{108}$ History adds an awareness of complexity in seeking social explanations, which is a very good recipe for any public health research.

It is true that epidemiology has afforded more depth to multilevel studies on the complex social and environmental systems that are the context for health and disease. However, limitations in its theoretical basis ${ }^{109}$ and/or inadequate consideration of the historical context can reduce the value of these studies. ${ }^{110}$ The use of a historical perspective to examine the plurality of determinants in any particular 
health condition will help to solve the longlasting debate on the primacy of individual versus population factors, which has been particularly intense in recent times. ${ }^{71}$

Finally, the use of history can improve epidemiology and public health through the design of causality models. Recent controversies have shown that the plural nature of problems imposes the selection of different research models. ${ }^{28}{ }^{37}$ Historical research can generate theoretical frameworks to explain disease and determinants of disease in a particular human community $^{37111}$ and can make a major contribution to these debates.

Translated from Spanish by Victor Pina and Richard Davies.

Funding: Enrique Perdiguero and Esteban Rodríguez-Ocaña are funded by the Spanish Ministry of Education and Culture (Research Projects PB97-0782-C03-02 and PB97-0782-C0301)

Conflicts of interest: none.

1 Sundin J. Why Hygiea Internationalis. Hygiea Internationalis 1999;1:5-8.

2 Labisch A. Homo Hygienicus. Gesundheit und Medizin in der Neuzeit. Frankfurt: Campus, 1992

3 Porter D. Health, civilization, and the state. A history of public health from ancient to modern times. London: Routledge, 1998.

4 Porter D, ed. The history of public health and the modern state. Amsterdam: Rodopi, 1994.

5 Coleman W. Death is a social disease. Public health and political economy in early industrial France. Madison: University of Wisconsin Press, 1982.

6 Riley J. The eighteenth-century campaign to avoid disease. Riley J. The eighteenth-century cam
London: Macmillan Press, 1987.

7 Weindling P. Health, race and German politics between national unification and Nazism, 1870-1945. Cambridge: Cambridge University Press, 1989.

8 Solomon SG, Hutchinson JF, eds. Health and society in revolutionary Russia. Bloomington: Indiana University Press, 1990.

9 Stepan NL. The hour of Eugenics. Race, gender and nation in Latin America. Ithaca: Cornell University Press, 1991.

10 Hamlin C. Public health and social justice in the age of Chadwick: Britain, 1800-1854. Cambridge: Cambridge University Press, 1998.

11 Baldwin P. Contagion and the state in Europe 1830-1930. Cambridge: Cambridge University Press, 1999.

12 Rosenberg CE. Explaining epidemics and other studies in the history of medicine. Cambridge: Cambridge University Press, 1992.

13 Porter D. The history of public health: current themes and approaches. Hygeia Internationalis 1999;1:9-21.

14 Labisch A. History of public health-History in public health: looking back and looking forward. Soc Hist Med 1998;11:1-13.

15 Fee E, Brown T. Why history? Am f Public Health 1997; 87:1763-4

16 Berridge V. History in public health: a new development for history? Hygiea Internationalis 1999;1:23-36.

17 Marset P, Rodríguez Ocaña E, Sáez JM. La Salud Pública en España. In: Martínez Navarro F, Antó JM, Castellanos JL, et al, eds. Salud Pública. Madrid: MacGraw-Hill Interamericana, 1998:25-47.

18 Bernabeu Mestre J, Gascón Pérez E. Historia de la Enfermería de Salud Pública en España (1860-1977). Alicante: Universidad de Alicante, 1999.

19 Huertas García-Alejo R, ed. Salud Pública en la España Contemporánea. Dynamis 1994;14:17-225.

20 Huertas García-Alejo R, ed. Salud Pública en la España Contemporánea (II). Dynamis 1995;15:155-299.

21 Perdiguero E. Problemas de salud e higiene en el ámbito local. In: Bernabeu Mestre J, Esplugues Pellicer X, Robles González E, eds. Salut $i$ malaltia en els municipis valencians. González E, eds. Salut i malaltia en els municipis valencians. Benissa: Seminari de Estudis sobre la

22 Rodríguez Ocaña E. La constitución de la Medicina Social como disciplina en España. Madrid: Ministerio de Sanidad y Consumo, 1987.

23 Rodríguez Ocaña E. Por la salud de las naciones. Higiene, microbiología y medicina social. Madrid: Akal, 1992.

24 Rodríguez Ocaña E. La salud pública en España en el contexto europeo, 1890-1925. Rev Sanid Hig Publica (Madrid) 1994;6:11-27.

25 Rodríguez Ocaña E. Foreign expertise, political pragmatism and professional elite: The Rockefeller Foundation in Spain, 1919-39." Stud Hist Phil Biol Biomed Sci 2000;31 447-61.

26 Rodríguez Ocaña E, Molero Mesa J. La cruzada por la salud. Las campañas sanitarias del primer tercio del siglo salud. Las campañas sanitarias del primer tercio del siglo
veinte en la construcción de la cultura de la salud. In: Montiel L, ed. La salud en el estado de bienestar. Análisis histórico. Madrid: Editorial Complutense, 1993:133-48.
27 Rodríguez Ocaña E, Bernabeu Mestre J. Physicians and statisticians. Two ways of creating the health statistics in statisticians. Two ways of creating the health
Spain. Continuity and Change 1997;12:247-64.

28 Krieger N. Epidemiology and the web of causation: Has anyone seen the spider? Soc Sci Med 1994;39:887-903.

29 Pearce N. Traditional epidemiology, modern epidemiology, and public health. Am F Public Health 1996;86:678-83.

30 Krieger N, Zierler S. What explains the public's health? A call for epidemiologic theory. Epidemiology 1996;7:107-9.

31 Susser M. Should the epidemiologist be a social scientist or a molecular biologist? Int $\mathcal{F}$ Epidemiol 1999;28:S1019-21.

32 García Benavides F. Epílogo para después de un paseo con Don Marcelino Pascua. Rev Esp Salud Pública 2000; 74:958.

33 Haeser H. Lehrbuch der Geschichte der Medicin und der epidemischen Krankheiten. 3 vols, 1875-82. [Reprint]. mischen Krankheiten. 3 vols, 187

34 Carreras Panchón A. Foaquín de Villalba (1752-1807) y los orígenes de la historiografía médica española. Málaga: Univerorigenes de la historiografia

35 Lesky E. Die Wiener medizinische Schule im 19. Fahrhundert. Graz-Köln: Verlag Herman Böhlaus Nachf, 1965.

36 Sudhoff K. Kurzes Handbuch der Geschichte der Medizin. Berlin: S Karger, 1922

37 Susser M, Susser E. Choosing a future for epidemiology: II. From black box to Chinese boxes and eco-epidemiology. Am F Public Health 1996;86:674-7.

38 Hauser P. Introducción al estudio de la Higiene. In: Salvat y Navarro A. Tratado de Higiene. Barcelona: M Marín, 1926: $5-63$.

39 Fee E. The origins and development of public health in the US. In: Holland WW, Detels R, Knox G, eds. Oxford textbook of public fealth. 2nd ed. Oxford: Oxford University Press, 1991:vol 1:3-22.

40 Lewis J. The origins and development of public health in the UK. In: Holland WW, Detels R, Knox G, eds. Oxford textbook of public health. 2nd ed. Oxford: Oxford University Press, 1991: vol 1:23-34

41 Tatara K. The origins and development of public health in Japan. In. Holland WW, Detels R, Knox G, eds. Oxford textbook of public health. 2nd ed. Oxford: Oxford University Press, 1991: vol 1:35-48.

42 MacMahon B, Trichopoulos D. Epidemiology. Principles and methods. 2nd ed. Boston: Little, Brown, 1996:4-14.

43 Fee E, Morman ET. Doing history, making revolution. The aspirations of Henry E Sigerist and George Rosen. In: Porter D, Porter R, eds. Doctors, politics and society. Historical essays. Amsterdam: Rodopi, 1993:275-311.

44 Porter D. The mission of social history of medicine. A historical overview. Soc Hist Med 1995;8:345-59.

45 Susser M, Susser E. Choosing a future for epidemiology: I. Eras and paradigms. Am f Public Health 1996;86:668-73.

46 Susser M. Does risk factor epidemiology put epidemiology at risk? Peering into the future. F Epidemiol Community at risk? Peering into the

47 Morabia A. Epidemiology and bacteriology in 1900: Who is the handmaid of whom? I Epidemiol Community Health 1998;52:617-18

48 Schwartz S, Susser E, Susser M. A future for epidemiology? Annu Rev Public Health 1999;20:15-33.

49 Winkelstein WJr. Interface of epidemiology and history: a commentary on past, present, and future. Epidemiol Rev 2000;22:2-6.

50 Peset JL, Peset M. Muerte en España. Política y sociedad entre la peste y el cólera. Madrid: Seminarios y Ediciones, 1972.

51 Pérez Moreda V. El paludismo en España a fines del siglo XVIII: la epidemia de 1786. Asclepio 1982;34:295-316.

52 Riera J. Fiebres y paludismo en la España Ilustrada. Valladolid: Universidad de Valladolid, 1984.

53 Mateu E. Arroz y Paludismo. Valencia: Edicions Alfons el Magnànim, IVEI, 1987.

54 Riera J, Granda Juesas J. Epidemias y paludismo en la Ribera del fucar. Valladolid: Universidad de Valladolid, 1988

55 Riera Palmero J, Rojo Vega A. Spanish agriculture and malaria in the 18th century. Hist Phil Life Sci 1988;10:34362 .

56 Riera Palmero J. Work, rice and malaria in Valencia in the XVIIIth century. Physis 1994;31:772-85.

57 Nájera JA. Esperanzas y desilusiones en el control de la malaria. $2^{\circ}$ Congreso de la Sociedad Española de Medicina Tropical y Salud Internacional. Sitges (Barcelona). 27-29 de enero de 2000.

58 Hackett L. Malaria in Europe: an ecological study. Oxford: Oxford University Press, 1937.

59 Löwy I, Zylberman P. Medicine as a social instrument. Rockefeller Foundation, 1913-1945. Stud Hist Phil Biol Biomed Sci 2000;31:365-79.

60 The malaria challenge after one hundred years of Malariology. (Papers from the Malariology Centennial Conference). Parassitologia 1999;41:1-528.

61 Mackenbach JP. The epidemiologic transition theory. F Epidemiol Community Health 1994;48:329-32.

62 Castellanos PL. Los modelos explicativos del proceso saludenfermedad: los determinantes sociales. In: Martínez Navarro F, Antó JM, Castellanos PL et al, eds. Salud Pública. Madrid: MacGraw-Hill Interamericana, 1998:81-102.

63 Huertas, R. Neoliberalismo y políticas de salud. Barcelona: El Viejo Topo, 1998.

64 Fee E, Brown T. A century of progress in public health? Am f Public Health 1999;89:1627-9.

65 Fee E, Brown T. The past and future of public health practice. Am F Public Health 2000;90:690-1.

66 Brandt AM, Gardner M. Antagonism and accomodation: interpreting the relationship between public health and 
medicine in the United States during the 20th Century. Am 7 Public Health 2000;90:707-15.

67 Rosner D, Markowitz G. Deadly dust. Silicosis and the politics of occupational disease in 20th c. America. Princeton, NJ Princeton University Presss, 1991.

68 Diez-Roux AV. Bringing context back into epidemiology: variables and fallacies in multilevel analysis. Am F Public Health 1998;88:216-22.

69 Diez-Roux AV. Multilevel analysis in public health research Annu Rev Public Health 2000;21:171-92.

70 García Ballester L. Improving health. A challenge to European medieval galenism. Sheffield: European Association for the History of Medicine and Health [Evening Lecture Series, no 2], 1996.

71 Pearce N. Epidemiology as a population science. Int F Epidemiol 1999;28:S1015-18

72 Barret R, Kuzawa CW, McDade T, et al. Emerging and re-emerging infectious diseases: The Third Epidemiologic re-emerging infectious diseases: The Third Epidem

73 Rogers N. Dirt, flies and immigrants: explaining the epidemiology of poliomyelitis, 1900-1916. F Hist Med Allied Sci miology of poliom

74 Tomes N. The private side of public health: sanitary science, domestic hygiene, and the germ theory, 1870-1900. Bull Hist Med 1990;64:504-39.

75 Hamlin C. Predisposing causes and public health in early nineteenth-century medical thought. Soc Hist Med 1992;5 43-70.

76 Leavitt J W. "Typhoid Mary" strikes back. Bacteriological theory and practice in early twentieth-century public health. Isis 1992;83:608-29.

77 Rodríguez Ocaña E. Medicina y epidemias. De la racionalizacion del mito al mito de la racionalizacion. In: Barona JL, ed. Malaltia $i$ cultura. València: Seminari d'Estudis sobre la Ciència, 1995:207-24.

78 Creese A. Global trends in health care reform. World Health Forum 1994;15:317-22.

79 Berlinguer G. Globalización y Salud Global. Salud $y$ Sociedad 1999;1:69-76.

80 Göckenjan G. Kurieren und Staat machen. Gesundheit und Medizin in der bürgerlichen Welt. Frankfurt: Suhrkamp, Medizin.

81 Porter D, Porter R, eds. Doctors, politics and society. Historical essays. Amsterdam: Rodopi, 1993.

82 Rosen G. A history of public health. New York: MD Publications, 1958.

83 Rosen G. A history of public health. Introduction by Elizabeth Fee. Biographical essay and new bibliography by Edward T Morman. Expanded edition. Baltimore: Johns Hopkins University Press, 1993.

84 Lupton D. Medicine as culture. Illness, disease and the body in Western societies. London: Sage, 1994.

85 Lupton D. The imperative of health: public health and the regulated body. London: Sage, 1995.

86 Berlinguer G. Storia e politica della salute. Milan: Franco Angeli, 1991 .

87 Huertas R. Organización sanitaria y crisis social en España. La discusión sobre el modelo de los servicios sanitarios públicos en el primer tercio del siglo XX. Madrid: Fundación de Investigaprimer tercio del siglo XX.

88 Crosby A. America's forgotten pandemia: the influenza of 1918. Cambridge: Cambridge University Press, 1989

89 Van Hartesvedlt FR, ed. The 1918-1919 pandemic of influenza. The urban impact in the Western world. Lewsiton, NY: Edwin Mellen, 1992.
90 Porras Gallo MI. Un reto para la sociedad madrileña: la epidemia de gripe de 1918-1919. Madrid: Comunidad de Madrid, Editorial Complutense, 1997.

91 Bernabeu Mestre J, ed. La ciutat davant el contagi. Alacante $i$ la grip de 1918-19. València: Generalitat Valenciana, Conselleria de Sanitat i consum, 1991

92 Bernabeu Mestre, Ramos Segura JR. Malaltia, poder i control social: el desallotjament de la barriada alicantina de les Provincies amb motiu de la grip de 1918. In: Puig-Pla C, Camós A, Arrizabalaga J, et al, eds. III Trobades d'Història de la Ciència $i$ de la Técnica. Barcelona: Societat Catalana d'Historia de la Ciència i de la Tècnica, 1995:215-21.

93 Campos R. La sociedad enferma: higiene y moral en España en la segunda mitad del siglo XIX y principios del XX. Hispania 1995;3:1093-112.

94 Bourdelais P, ed. Hygiène et hygiénistes: Histoire et actualité (XVIIIème-XIXème siècles). Lyon: Foundation M Mérieux (in press).

95 Bunton R, Nettleton S, Burrows R, eds. The sociology of health promotion. Critical analyses of consumption, lifestyle and risk. London: Routledge, 1995.

96 Montiel L, Porras I, eds. De la responsabilidad individual a la culpabilización de la victima. El papel del paciente en la preven -

97 Labisch A. The social construction of health: from early modern times to the beginnnings of the industrializaction. In: Lachmund J, Stollberg G, eds. The social construction of illness. Stuttgart: Franz Steiner, 1992:85-101.

98 Armstrong D. Public health spaces and the fabrication of identity. Sociology 1993;27:393-410.

99 Durkheim E. The elementary forms of the religious life: a study in religious sociology. Glencoe, IL: Free Press, 1947.

100 Douglas M. Purity and danger: an analysis of concepts of pollution and taboo. London: Routledge, 1966.

101 Foucault M. On governmentality. Ideology and consciousness 1979;6:5-22.

102 Johnson T. Governmentality and the institutionalisation of expertise. In: Johnson T, Larkin G, Saks M., eds. Health professions and the state in Europe. London: Routledge, 1995: $7-24$.

103 Jones C, Porter R, eds. Reassessing Foucault. Power, medicine and the body. London: Routledge, 1994.

104 Petersen A, Bunton R, eds. Foucault, health and medicine. London: Routledge, 1997.

105 Kelly MP, Charlton B. The modern and the postmodern in health promotion. In: Bunton R, Nettleton S, Burrows R, eds. The sociology of health promotion. Critical analyses of consumption, lifestyle and risk. London: Routledge, 1995:78-90.

106 Annandale E. The sociology of health and medicine. Cambridge: Polity Press, 1998.

107 McMichael AJ. Prisoners of the proximate: loosening the constraints on epidemiology in an age of change. Am f Epidemiol 1999;149:887-97.

108 Van Poppel, F, Van der Heijden,C. The effects of water supply on infant and childhood mortality: a review of historical evidence. Health Transit Rev 1997; 7:113-48.

109 Blakeley TA, Woodward AJ. Ecological effects in multilevel studies. F Epidemiol Community Health 2000;54:36774.

110 Pearce N. The ecological fallacy strikes back. $\mathcal{F}$ Epidemiol Community Health 2000;54:326-7.

111 Almeida, N. Epidemiología sin números. Una introducción crítica a la ciencia epidemiológica. Washington: OPS/OMS (Serie PALTEX para ejemplares de programas de salud, no 28), 1992. 